\title{
Agriculture in India.
}

$I^{1}$ NDIA nowadays is rarely without its Commission, and these follow one another in rapid succession. The most recent one reporting is the Royal Commission on Agriculture, ${ }^{1}$ which has been at work for the past two years, somewhat overshadowed latterly by the Simon Commission. The short title is rather misleading, for the terms of reference cover much wider ground : these include the "present position of agricultural and rural economy in India," and the Commission is asked to make "recommendations and to promote the welfare and prosperity of the rural population." Specifically mentioned besides agricultural and veterinary practice, are agricultural statistics, better crops and improvement in practice, dairy farming and breeding of stock, as well as methods of transport and marketing, agricultural finance and credit. But the intention of His Majesty's Government is perhaps more clearly indicated by the composition of the Commission, which includes no member of the Indian Agricultural Service.

For those, then, who might naturally look for a careful survey of the many problems facing Indian agriculture, the report will be somewhat disappointing. For a study of such questions they will have to depend chiefly on the mass of evidence which is now being published. The Commission contents itself, so far as the improvement of agriculture is concerned, with some 50-60 pages, but devotes a larger number of pages to the agricultural services and their organisation, having among its members those eminently fitted for dealing with this.

The Commission, in its letter of submission, writes as follows: "Throughout our Report we have endeavoured to make plain our conviction that no substantial improvement in agriculture can be effected unless the cultivator has the will to achieve a better standard of living and capacity, in terms of mental equipment and of physical health, to take advantage of the opportunities which science, wise laws, and good administration may place at his disposal. Of all the factors making for prosperous agriculture, by far the most important is the outlook of the peasant himself." When all is said and done, however, we do not think that the request in the terms of reference "in particular to investigate the measures now being taken for the promotion of agricultural research . . . the introduction of new and better crops, and improvement in agricultural practice," has received sufficient attention. The inclusion of experienced workers in these subjects would have strengthened the Commission, and rendered this part of its report more weighty and valuable.

The compact volume in which the report is printed runs to close on 900 pages, of which the first 100 are devoted to an unofficial summary, excellently written and of particular value to the general reader. We gather that the first step taken on landing in India was the preparation of the usual

1 Report of the Royal Commission on Agriculture in India. (Cmd. 3132.) Pp. v+100+xviii +755 . (London: H.M. Stationery Office, 1928.) 11s, net.

No. 3065, VoI. 122] questionnaire, which was very freely distributed. Replies to this numbered 783 , and 395 witnesses were examined during the two years. The mass of literature comprised of these written statements and the subsequent examinations should form a useful library on Indian agriculture, and the present conditions of the rural population.

The report opens with an introductory chapter on "The Village," the unit of rural India, which is entirely different from anything in Great Britain. It consists in the main of a collection of mud houses huddled together like a flock of frightened sheep, in the midst of the fields belonging to it. This arrangement dates from ancient times, and obviously makes for mutual protection, for the cultivators were defenceless against bands of marauders. Besides this, the demands of their rulers varied from vear to year and were sometimes crushing; and there was always the fear of famine if the monsoon failed. Selling the produce from their fields was non-existent in a small community all growing the same crops, and each cultivator was content with producing only the amount required for his family. Later, with added security under a settled government, matters improved, and there was a new-found feeling of safety. The land was divided up and the rights of ownership examined and recorded, and for the first time land, irrespective of crops, acquired a value. Each member of the village knew what proportion of the produce was his own-but the arrangement of centuries remained unaltered. Of the 500,000 villages in India, most are still untouched by metalled roads or railways, and are thus cut off from one another by impassable paths during the rains.

There is in India a marked absence of large-scale farming. All agricultural practices are dependent on the stated periods of the monsoons, and work on the land in the long dry season becomes impossible. Thus for half the year the cultivator has his time on his hands. It is always hard to change old-time customs, but not the least problem engaging the attention of the Commission appears to be that of placing the cultivator in a position, by the most varied ameliorations, to make use of this idle time.

In the second chapter there is a summary history of the efforts at applying scientific agriculture to India, from the enlistment of twelve American cotton planters in 1839 "to teach the cultivators to grow and clean cotton," and the celebrated order placed in England in 1863 by the Madras Government for "a steam plough, steam harrows and cultivators, seed drills, horse hoes, threshing machines and winnowers, chaff cutters and water lifts," to the establishment in 1903 by Lord Curzon of the Indian Agricultural Department. When the constitutional changes occurred in 1919 , all departments connected with rural welfare were 'transferred ' from the Government of India to the local governors, each acting through a minister. This of course included agriculture, with the exception of the central research stations for all India. 
In Chapter iii. the Commission, dissatisfied with the incoherence of the present arrangement, proposes a new organisation for agricultural research. This scheme, although the Commission is not quite unanimous in matters of detail, appears to be well thought out and of value. At present the agricultural departments in the provinces are independent of one another and of the central research institutes, which are under the control of the Agricultural Adviser to the Government of India. This lack of connexion between all India and provincial departments is, and always has been, an anomaly, and the new organisation is designed to bring them into closer relations. For this purpose the establishment of an Imperial Council of Agricultural Research, with a lump sum of 50 lakhs of rupees as endowment, is recommended; the primary function of the council will be to co-ordinate agricultural and veterinary research in India with that in other parts of the British Empire and foreign countries.

The Imperial Council of Agricultural Research would consist of three whole-time officers and 36 others. Of the three, the chairman should be of wide administrative experience and, if possible, with Indian experience also, and the two others would deal with agricultural and veterinary research respectively. The 36 ordinary members would represent various interests in the country: 8 would be nominated by the Government of India, 18 would represent the provinces, 3 the universities, 1 each the Central Cotton Committee and the planting community, and the remaining 5 would be elected by the Council itself. The whole-time officers would be engaged for five years, and the rest nominated for three, periods subject to extension if desired. The post of agricultural adviser to the Government of India would naturally lapse under this scheme, and his advisory duties would be carried on by the chairman of the Council.

Special attention is directed to the Central Research Institute at Pusa. This, it is recommended, should be strengthened so as to become also a teaching centre for higher training in agriculture, as it is entirely desirable that India should be self-contained in this respect as soon as possible.

The allied subject of the agricultural services is dealt with in a long chapter (xix.) at the end of the report. While we consider it of even greater importance than that on the organisation of research, space forbids us from going into details. The general intention in the recommendations is to improve the status of these services, on the score of efficiency and because of the increased responsibilities imposed if the Commission's suggestions are endorsed. This applies not only to the rank and file, but in a special degree to the posts of provincial director of agriculture and the principal of the agricultural college, both of them being key positions in the improvement of agriculture. It is suggested that the hands of the former might be strengthened by the addition of an officer of somewhat lower status as joint director. The Commission is not in favour of short-term appointmentswhich are, it is true, generally uneconomic in principle and practice. As to the general recruitment for the service, it is recommended that the system of scholarships so successfully initiated by the Colonial Office should be adopted; and in the case of all superior officers it is contended that the best men should be engaged, and that therefore recruitment should not be confined to one province, or even to India. The Institute at Pusa is again referred to, and the Commission recommends that the status of the principal and the heads of sections should be raised, in view of the increased demands made upon them.

Chapter vi. is devoted to agricultural improvement, and it is stated that the various factors affecting crop production, other than irrigation, are dealt with. The areas under the seventeen chief crops in India are given for general information. Soils and manures are rather fully discussed and take up about half of the chapter, a few pages are devoted to plant breeding, and a table is printed showing the areas under improved varieties ; rather more space is devoted to seed distribution; agricultural implements are then considered, and a few concluding remarks are made on plant protection. The important subjects of rotation of crops and tillage are not included, in that they have been fully discussed by the recent Sugar and Cotton Committees.

There are 81 recommendations and conclusions at the end of chapter vi, although this formidable number could have been reduced by using longer paragraphs. As examples of useful conclusions the following may be given : the suggestion that a soil survey of India should be undertaken is vetoed : no diminution in the fertility of long-continued cultivated fields is anticipated : definite advice cannot be given by the agricultural department on the use of fertilisers by cultivators: neither export tax nor prohibition of export, of oil seeds, oil cakes, bones or fish manures, can be justified; and no legislation is needed for the adulteration of fertilisers.

As already indicated, we consider that this chapter will prove disappointing to those interested in agricultural problems, and hoping for new light on an extremely complicated enterprise, in which, despite occasional successes, the general result of their labour has often been very disheartening. This latter aspect is reflected in the way in which the Commission has presented this part of its report; for there is a singular absence of that enthusiasm which is so marked a feature whenever they deal with rural economy. As it is, the chapter summarises the information placed before the Commissioners, and is simple and clear, with an honest attempt to make suggestions where considered of possible advantage. In many cases there is practically nothing to be done but to go on working, and the Commission accordingly has various suggestions for the new Imperial Council of Agricultural Research. But it must be remembered that this subject is rather beyond the experience of the Commission as constituted, and could only be dealt with properly by a committee of experts in the various agricultural sciences, and in the practical aspects of Indian agriculture : such a body alone would be competent to collate the evidence and to discuss the improvement of Indian agriculture.

( $T$ To be continued.) 